UDC 531.

DOI $10.36910 / 6775-2313-5352-2020-16-13$

A. Perederko, Ph.D.

Odessa state academy of technical regulation and quality

\title{
SIGNAL PHASE SHIFTS DURING THE MEASUREMENT OF VIBRATION PARAMETERS
}

Abstract. In systems of vibration control, monitoring, diagnostics, active vibration protection, measurements and control of vibration parameters are necessary. For this, piezoelectric sensors are widely used in them as primary transducers. These sensors, due to their high metrological characteristics, such as accuracy, speed, a wide band of operating frequencies and temperatures, are traditionally used to measure vibration displacement, vibration velocity and vibration acceleration. The use of these types of sensors is necessary due to the need to measure and control vibration at objects with different frequency characteristics. The article considers possible distortions of the measured signal at the output of the sensors due to phase shifts. These phase shifts must be taken into account when developing and constructing measurement and processing schemes of the vibration signal. This is especially true when measuring and recording a rapid vibration processes, such as mechanical shock.

Keywords: vibration, phase shift, sensors for vibration measurement, vibrometer, accelerometer.

Introduction and statement of the problem. At the stages of development, testing and operation of various technical and technological devices, much attention is paid to the study of vibration. In recent years, measuring and information systems of vibration control, monitoring, diagnostics, active vibration protection have become widespread, that not only provides a large technical and economic effect, but also helps to prevent accidents and possible technological and environmental disasters [1,2].

The initial link of such systems is vibration and shock vibration parameters sensors located directly on the controlled object. They convert the measured mechanical value into an electrical signal supplied to the measuring device for further processing [3,4].

Sensors of vibrational parameters often work under difficult adverse conditions - at high temperatures, strong alternating magnetic fields, intense vibrational and shock overloads [5], high pressure and penetrating radiation. They are subject to special requirements for the accuracy and reliability of measurements.

Therefore, their study and improvement is an urgent issue of our time.

The aim of the work. To investigate the model of piezoelectric transducers used as sensors during the measurement of vibration parameters for their phase characteristics and phase distortions. Which are important in the study of short-term mechanical vibrations and shocks.

Results of the work. From all the variety of existing sensors for measuring vibration parameters, sensors with piezoelectric transducers have become the most common. Sensors designed to measure vibration displacement (shift) are called vibrometers. Sensors that measure vibration velocity are called velocimeters, and the ones that measure acceleration are called accelerometers.

Vibration acceleration belongs to non-electrical values that cannot be transformed into an electrical signal without additional transformations, so functionally intermediate transformations are performed by a sensitive element of the sensor.

Figure 1 shows the calculated model of the piezoelectric vibration sensor.

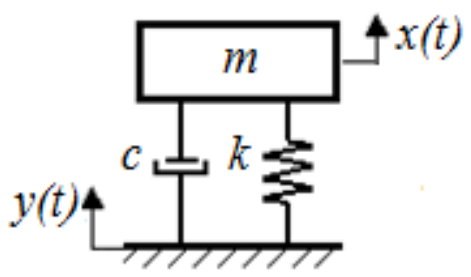

Fig. 1. Calculated model of the piezoelectric vibration sensor.

(C) Передерко А.Л., к.т.н. 
The model (Fig. 1) consists of mass $m$, spring $k$ and damper $c$, which are located on the stand. The stand is attached to the vibrating object. With this arrangement, the lower end of the spring and the damper will have the same movement as the stand (movement $y$ to be measured). Then the displacement of the mass relative to the stand will be $z=x-y$, where $x$ is the vertical displacement of the mass $m$.

In this case, the vibrating object is subjected to harmonic motion:

$$
y(t)=Y \sin \omega t .
$$

The equation of mass $m$ can be written as:

$$
\ddot{m} x+c(\dot{x}-\dot{y})+k(x-y)=0
$$

Determining the relative displacement of $z$ as:

$$
z=x-y \text {. }
$$

Equation (2) can be written as:

$$
m \ddot{z}+c \dot{z}+k z=-m \ddot{y}
$$

Equations (1) and (4) result in:

$$
m \ddot{z}+c \dot{z}+k z=-m \omega^{2} Y \sin \omega t,
$$

therefore, the stationary solution is given by the method:

$$
z(t)=Z \sin (\omega t-\phi),
$$

where $Z$ and $\phi$ are given by equations (8) and (9), respectively:

$$
\begin{gathered}
z(t)=\frac{m \omega^{2} Y \sin (\omega t-\phi)}{\sqrt{\left(k-m \omega^{2}\right)^{2}+\left(c^{2} \omega^{2}\right)}}=Z \sin (\omega t-\phi) . \\
Z=\frac{m \omega^{2} Y}{\sqrt{\left(k-m \omega^{2}\right)^{2}+\left(c \omega^{2}\right)}} . \\
\phi=\tan ^{-1}\left(\frac{c \omega}{k-m \omega^{2}}\right)=\tan ^{-1}\left(\frac{2 \zeta r}{1-r^{2}}\right) .
\end{gathered}
$$

Where: $r=\frac{\omega}{\omega_{n}}, \quad \zeta=\frac{c}{2 m \omega_{n}}$.

As can be seen from equation (6), the devices measuring the vibration parameters [6] have a phase lag. Thus, the output of the measuring device lags behind the input effect. The delay time is measured by the phase angle divided by the frequency $\varpi$. Time delay is not important if we measure one harmonic component. But, in most cases, the vibration measured is not harmonic and consists of the sum of two or more harmonic components. In this case, the saved measurement data can give an inaccurate picture of vibration during further mathematical processing or on a graph. Since different harmonics can be amplified by different coefficients their phase shifts can also be different. The wave distortion of the recorded signal is called phase distortion or phase shift error. To illustrate the nature of the phase shift error, consider the vibration signal:

$$
y(t)=a_{1} \sin \omega t+a_{3} \sin 3 \omega t
$$

Simulation of vibration signals was performed in the MATHCAD system. The shape of the vibration signal (10) is shown on Fig.2. 
Suppose that for the first harmonic there was a phase shift $90^{\circ}$ and $180^{\circ}$ for the third harmonic of equation (10). The corresponding time lags are set through $t_{1}=90^{\circ} / \omega$ and $t_{2}=180^{\circ} /(3 \omega)$.

The output signal is shown in Fig.3. It is seen that the output signal is very different from the input signal due to phase distortion. As a general case, let a given complex wave be given by the sum of several harmonics as

$$
y(t)=a_{1} \sin \omega t+a_{2} \sin 2 \omega t+\ldots
$$

If the displacement is measured with, for example, a vibrometer, then its response to each component of the series is given by an equation similar to equation (6). So the output of the vibrometer will be:

$$
\begin{aligned}
& z(t)=a_{1} \sin \left(\omega t-\varphi_{1}\right)+a_{2} \sin \left(2 \omega t-\varphi_{2}\right)+\ldots \\
& \text { Where } \tan \varphi_{j}=\frac{2 \zeta\left(j \frac{\omega}{\omega_{n}}\right)}{1-\left(j \frac{w}{\omega_{n}}\right)^{2}}, \quad j=1,2, \ldots
\end{aligned}
$$

Since the ratio $\omega / \omega_{n}$ for the vibrometer is large, then $\phi_{j} \square \pi, j=1,2 \ldots$, and equation (12) becomes:

$$
z(t) \square-\left[a_{1} \sin \omega t+a_{2} \sin 2 \omega t+\ldots\right] \square-y(t)
$$

Thus, the output signal will be inverse to the measured motion.

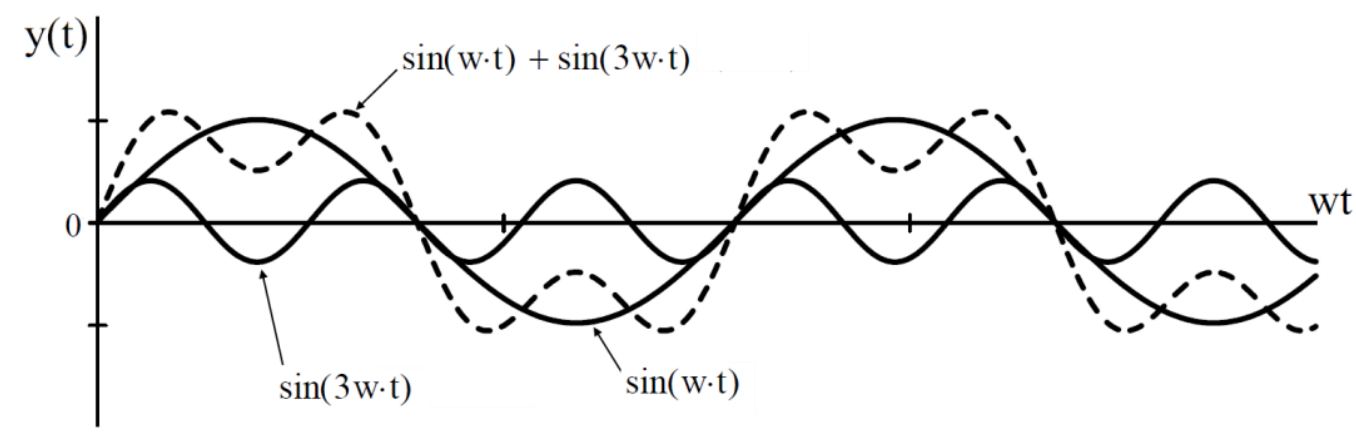

Fig.2. Shape of vibration signal.

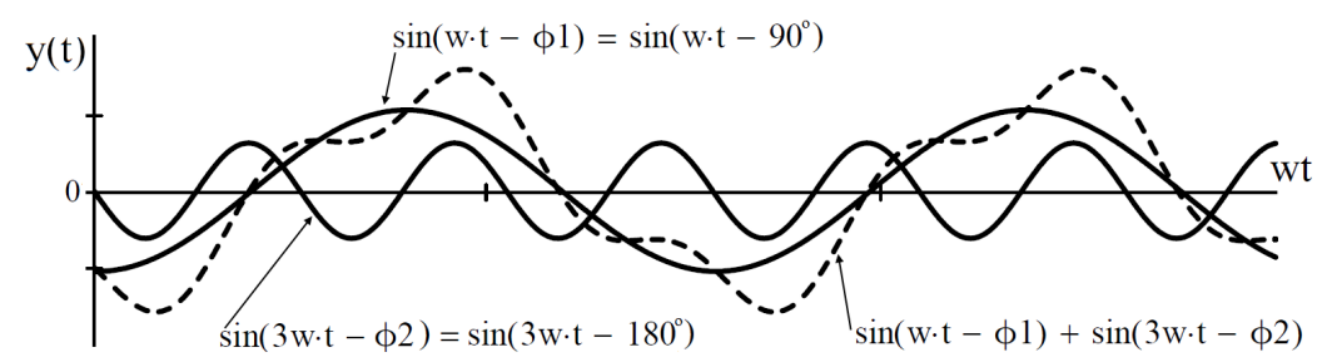

Fig. 3. Phase shift error.

Using a similar reasoning, we can show on the example of a velocimeter that

$$
\dot{z}(t) \square-\dot{y}(t)
$$

for an input signal that consists of several harmonics.

Let's consider the phase shift for the accelerometer. Let the acceleration signal for the measurement be expressed using equation (11) as

$$
\ddot{y}(t)=-a_{1} \omega^{2} \sin \omega t-a_{2}(2 \omega)^{2} \sin 2 \omega t-\ldots
$$


The answer or output of the accelerometer for each component can be found as in the equation. (12)

$$
\ddot{z}(t)=-a_{1} \omega^{2} \sin \left(\omega t-\varphi_{1}\right)-a_{2}(2 \omega)^{2} \sin \left(2 \omega t-\varphi_{2}\right)-\ldots
$$

where the phase lags $\phi_{j}$ are different for different components of the series in equation (17). Since the phase lag $\phi$ varies almost linearly from $0^{\circ}$ at $r=0$ to $90^{\circ}$ at $r=1$ for $\zeta=0.7$ we can express $\phi$ as

$$
\phi \square \operatorname{ar}=a \frac{\omega}{\omega_{n}}=\beta \omega
$$

where $\alpha$ and $\beta=\alpha / \omega_{n}$ are constants. The delay time is set

$$
t^{\prime}=\frac{\phi}{\omega}=\frac{\beta \omega}{\omega}=\beta
$$

This indicates that the time lag of the accelerometer does not depend from the frequency for any component, provided that the frequency is in range $0 \leq r \leq 1$. Since each component of the signal has the same time delay or phase lag, we have, from equation (17),

$$
\begin{aligned}
& -\omega^{2} \ddot{z}(t)=-a_{1} \omega^{2} \sin (\omega t-\omega \beta)-a_{2}(2 \omega)^{2} \sin (2 \omega t-2 \omega \beta)-\ldots \\
& =-a_{1} \omega^{2} \sin \omega \tau-a_{2}(2 \omega)^{2} \sin 2 \omega \tau-\ldots
\end{aligned}
$$

where $\tau=t-\beta$. Note that equation (20) assumes that $0 \leq r \leq 1-$ that is, even the highest frequency, $n \omega$, is less than $\omega_{n}$.

Of course, this is not achieved in practice. But, in the real output signal, there is no significant phase distortion even when some frequencies of a more higher order exceed $\omega_{n}$. The reason is that, as a rule, only the first few components are important for the approximation of even a complex waveform. The amplitudes of the higher harmonics are small and have very little effect on the overall shape of the signal. Thus, the output signal of the accelerometer has a shape close to the shape of the acceleration being measured.

\section{Conclusions:}

1. When using vibration measuring equipment, it is necessary to take into account the phase characteristics of the charge or voltage amplifiers used together with the considered piezoelectric sensors.

2. Particular attention should be paid to the use of equipment equipped with electronic integrators and filters. Issues related to phase response and phase distortion are especially important in the study of short-term mechanical oscillations and mechanical shocks.

\section{References}

1. Harris' Shock and Vibration Handbook, Cyril M. Harris, editor, Allan G.Piersol, editor, 5th ed., McGraw-Hill 2002.

2. J. Tuma, J. Kulhanek, "Using scripts in Signal Analyzer". In: 8th International Scientific Technical Conference Process Control 2008, Editor Taufer, Ivan. 1. edition Pardubice : Ceska spolecnost prumyslove chemie, June 9-12, 2008, Kouty nad Desnou, Czech Republic.

3. J. Edward Alexander. Shock Response Spectrum - A Primer Sound \& Vibration/June 2009.

4. Harris S. Handbook of shock loads. / S.M. Harris, C.I. Creed // L .: Shipbuilding, 1980.

5. Subbotin S. Spectral characteristics for comparison and identification of impact loads / S. G. Subbotin, A. Yu. Melnikova // Factory Laboratory. Diagnostics of materials, 2009. No. 12 (75). S. $53-$ 56. ISSN 1028-6861.

6. Perederko A. Mathematical models of piezoelectric sensors for measuring vibration parameters / A.L. Perederko. // Measuring and computing devices in technological processes. 2019, Issue 2. ISSN 2219-9365.

7. Karazin V. Features of modeling and reproduction of vibroimpact effects / V.I. Karazin V.I., S.V. Kolesnikov, S.D. Litvinov et al. // Theory of mechanisms and machines. 2013. No. 2 (11). ISSN 0236-3941.

8. Carl Sisemore, Vít Babuška. The Science and Engineering of Mechanical ShockSpringer // ISBN 978-3-030-12103-7 (eBook).Nature Switzerland AG 2020. 
9. Tretyakov A. Calculation of the shock response spectrum when testing portable tanks and gas containers/ A.V. Tretyakov, O.A. Tretyakov, M.V. Zimakova // Transport of the Russian Federation, No. 3 (58) 2015.

10. Voskoboinikov Yu. E. Solution of engineering problems in the MathCAD package / Yu. E. Voskoboinikov (and others); under the editorship of Yu. E. Voskoboinikova. - Novosibirsk: NGASU (Sibstrin), 2013 .

Передерко А.Л., к.т.н.

Одесская государственная академия технического регулирования и качества

\section{ФАЗОВЫЕ СДВИГИ СИГНАЛА ПРИ ИЗМЕРЕНИИ ВИБРАЦИОННЫХ ПАРАМЕТРОВ}

В системах вибрационного контроля, мониторинга, диагностики, активной виброзащиты необходимы измерения и контроль параметров вибрачии. Для этого в них, в качестве первичных преобразователей, широко применяются пьезоэлектрические датчики. Эти датчики, благодаря своим высоким метрологическим характеристикам, таким как точность, быстродействие, широкая полоса рабочих частот и температур, традиционно используются для измерения виброперемещения, виброскорости и виброускорения. Применение этих типов датчиков обусловлено необходимостью измерения и контроля вибрачии на объектах с различными частотными характеристиками. В статье рассмотрены возможные искажения измеряемого сигнала на выходе датчиков за счет фазовых сдвигов. Эти фазовые сдвиги необходимо учитывать при разработке и построении схем измерения и обработки сигнала вибрации. Особенно это актуально при измерении и регистращии быстротекущих вибрачионных процессов, например таких как механический удар.

Ключевые слова: вибрация, фазовый сдвиг, датчики для измерения вибрации, виброметр, акселерометр.

Передерко А.Л., к.т.н.

Одеська державна академія технічного регулювання та якості

\section{ФАЗОВІ ЗРУШЕННЯ СИГНАЛУ ПРИ ВИМІРЮВАННІ ВІБРАЦЙНИХ ПАРАМЕТРІВ}

В системах вібраційного контролю, моніторингу, діагностики, активного віброзахисту необхідні вимірювання і контроль параметрів вібрації. Для иьього в них, в якості первинних перетворювачів, широко застосовуються п'єзоелектричні датчики. Ці датчики, завдяки своїм високим метрологічним характеристикам, таким як точність, швидкодія, широка смуга робочих частот $i$ температур, традиційно використовуються для вимірювання вібропереміщення, віброшвидкості $і$ віброприскорення. Застосування иих типів датчиків обумовлено необхідністю вимірювання і контролю вібрації на об'єктах з різними частотними характеристиками. У статті розглянуто можливі спотворення вимірюваного сигналу на виході датчиків за рахунок фазових зрушень. Ці фазові зрушення необхідно враховувати при розробиі та побудові схем вимірювання та обробки сигналу вібраџіi. Особливо це актуально при вимірюванні та реєстраиї швидкоплинних вібраційних процесів, наприклад таких як механічний удар.

Ключові слова:: вібрачія, фазовий зсув, датчики для вимірювання вібрачії, віброметр, акселерометр. 